\title{
PACIFYING THE RADICALS: RELIGIOUS RADICALISM, ISLAMIST MILITANCY AND PEACEBUILDING APPROACHES IN CONTEMPORARY INDONESIA
}

\author{
Sumanto Al Qurtuby \\ Department of Global and Social Studies, \\ King Fahd University of Petroleum and Minerals, \\ Saudi Arabia \\ (alqurtuby@kfupm.edu.sa) \\ DOI: https://doi.org/10.22452/jati.vol24no1.1
}

\begin{abstract}
This article aims to examine the rise of religiously-inspired violent extremism and Islamist militancy, which challenges democracy and civic pluralism in contemporary Indonesia. Additionally, this article offers possible ways of resolving conflict and building peace and dialogue with the radicals and Islamists in this archipelagic country. Following the political reformation in 1998 that marked the end of the New Order rule, violent conflict and Islamist radicalism broke out in some areas of Indonesia. There have been numerous types of violence in post-Suharto Indonesia, each with different roots, objectives, factors and histories. This article, however, focuses solely on religious violence and Islamist militancy, and it examines models, approaches and practices of conflict transformation and strategic peacebuilding that are suitable for Indonesian society. This article emphasises the role of law and justice, local power capacity, and some aspects of religion, local tradition, and culture as focal resources for building peace and resolving violent conflicts.
\end{abstract}

Keywords: religious violence, Islamist militancy, conflict resolution, peacebuilding, Indonesia

\section{Introduction}

Following the political reformation in 1998 - which marked the end of Suharto's New Order dictatorial government - violent conflict, Islamist radicalism, terrorism and anti-pluralist movements broke out in some areas of Indonesia. Various Islamist factions, intolerant religious groupings and radical Salafis, 
either of local or foreign origin, which had been "mummified" during the Suharto regime began appearing across the country, including in the remote area of Papua. Their appearance threatens prolonged civil coexistence and ethnoreligious tolerance in this archipelagic country.

This article investigates the underlying factors of, motives behind and actors involved in the religious violence, intolerance and Islamist militancy that could hinder the process of post-New Order democracy and socio-political reformation. It explores the historical dynamics of religious militancy and interreligious relations before and after the New Order in order to understand the modern phenomena of religious/Islamist radicalism. Finally, the article investigates ways of addressing and resolving the religious violence, Islamist extremism, intolerant actions and anti-pluralist movements as well as establishing conciliation and dialogue in the country.

While there is sizable academic literature on Indonesia's religious violence and Islamist radicalism (e.g., Bertrand [2004]; Sidel [2006]; van Klinken [2007]), studies and scholarships on strategic approaches to conflict resolution and peacebuilding to minimise the violence and radicalism are still limited, though there are a few notable exceptions (e.g., Brauchler [2011, 2016]). Most scholars of Indonesian society do not pay attention to this subject. Therefore, this article fills the gap in the previous and existing studies and contributes to the research on the country's conflict resolution, dispute management and peacebuilding approaches.

This article defines religious violence simply as violence that is inspired or influenced by certain religious teachings, doctrines, discourses, practices or symbols and that is committed by individuals or groupings whose objectives are either religious or secular or both (Al Qurtuby, 2016). In other words, it is not the end (the goal) that determines violence's religious dimensions but rather the source of inspiration (for the violence) and actors engaged in the violent conflict and extremism. In fact, it is insignificant whether or not religious actors - both elites and ordinary masses - are involved in conflict for religious or secular purposes, such as political power, access to bureaucracy, land ownership, economic interests and so forth. As long as those involved in violence utilise religious sources of both doctrines and social capitals, it is referred to as 'religious violence' in this article.

The Indonesian case reminds us that those involved in acts of violence, intolerance and hostility are not all motivated by secular interests and rationales as many, if not most, liberal scholars have argued. Even scholars who admit the religious nature of violence, such as Sidel (2006), view religion as a substitute for bigger political and economic interests and overlook other ways that religion 
influences people's actions. Many scholars also fail to notice the significance participants place on religion and religious identity in conflict settings. Liberalminded scholars tend to dismiss the religious framing of violence and see religion simply as an instrument that elites utilise to mobilise the masses and networks and to manipulate religious symbols to attain political and economic aims. In reality, however, many grassroots Islamist actors and ordinary religious radicals who actually engage in violence and radicalism in contemporary Indonesia are essentially driven by and for religion and non-worldly matters, such as to defend the Islamic faith, erect religious identity or enter Heaven after death (see Hwang [2018]).

The religious militias engaged in the Maluku and North Maluku violence, for instance, actually used their political agenda and economic issues to camouflage the true religious goals of their violent acts, such as the annihilation of a particular religious community, dissemination or conversion of a particular faith and purification of a particular religious belief and thought, among others (Al Qurtuby, 2016; Duncan, 2013; Wilson, 2008). Research findings of the Indonesian Institute for Social and Religious Studies (Kholiludin, 2016), for instance, also showed that perpetrators of acts of religious violence and prejudice in some parts of Java were motivated or driven by the desire to purify some religious groupings, including local sects, which they dubbed irreligious and sesat (deviant). Religious desecration hence becomes one among many motives of those involved in acts of religious conflict and bigotry.

In addition to sparking violent extremism, religion is a significant element for establishing intergroup reconciliation, conflict resolution and conciliation. This phenomenon has occurred not only in Indonesia but also in other countries besieged by communal strife (see Appleby [2000]; Philpott [2012]). Based on the multiple peacebuilding cases of Indonesian society, scholars, practitioners and policymakers must go beyond a well-established liberal framework of violence and peace, which tends to ignore the importance of religion and culture in violence and peacebuilding. Instead, they must acknowledge religious-cultural significance in both discord and concord. One of the main challenges of conflict and peace studies is explaining the role or power of culture, tradition and religion - which includes beliefs, identities, social networks, material culture and the use of particular texts or imagery - in conflict and post-violence settings for instigating violence or supporting peace without trying to essentialise it.

Although religion is certainly an important source for peacemaking and conflict transformation, relying solely on this factor is insufficient. Those concerned with establishing an enduring intergroup peace must consider, for 
instance, religious-secular alliances and non-religious peacebuilding techniques, such as a legal-justice approach. In other words, building global peace requires a strategic, comprehensive approach that involves all vital and useful resources from the conflict-ridden society. This article is written on the basis of this theoretical premise. Data used for analysis in this article were mainly gathered from media reports, research findings of notable research institutions, secondary writings and primary documentations from Islamic institutions in Indonesia. Once the data were collected, I then borrow Max Weber's verstehen (emphatic understanding) and used an ethical approach to carefully interpret, analyse and understand the data and social facts. This article is also based on my close reading of previous and existing scholarship that lack analysis and investigation on integrative, reconciliatory and peaceful dimensions of Indonesia's plural society.

\section{Indonesia's Religious Violence and Radicalism}

The fall of Suharto in 1998 and the rebirth of liberal democracy led to the rise of a range of conservative militant groups, including Islamists, anti-pluralist groups, Muslim hardliners and other closed-minded Islamic organisations (see Hasan [2006]; Wahid [2014]). This, however, does not mean that all Muslims and Islamic groupings in the country have been intolerant, violent, radical/militant, antipluralist or closed minded, since there are indeed many Muslims who are tolerant, peaceful, pluralist and caring. It is also imperative to note that the term 'Islam' differs significantly from 'Islamism', and the word 'Islamist' is different from 'Muslim'. While Islam refers to the Islamic faith in general, Islamism is defined as a political ideology based on a reinvented version of Islamic law. Frequently used for the ideology of political Islam, Islamism seeks a greater role for Islam in the government, economy and society. Islamism's central agenda is for the state to become active in the enforcement of Sharia law and to uphold Islamic values and principles. An Islamist is a practitioner (individual or group) of Islamism, whereas a Muslim is an adherent of Islam (Islamic religion) in general (Hwang, 2012; Tibi, 2012).

Furthermore, in a free democratic society, the problem actually does not lie in the growth of these groups itself, but in what they do in the pursuit of their objectives, whether they commit violence and intolerant actions and how they utilise coercive means that are in opposition to principles of democracy, human rights and universal values. In many cases, these religious groups destroy properties belonging to their targets, but the damage is not only physical.

There is plenty of evidence that ethnoreligious communal violence, acts of intolerance and other human rights violations have been committed by 
militant Islamist groups in post-Suharto Indonesia not only in Java's major cities but also outside Java, including Christian-Muslim violence in Maluku, North Maluku and Poso (Al Qurtuby, 2016; Bertrand, 2004; Sidel, 2006; van Klinken, 2007). Sporadic terrorist acts and suicide bombings, some of which have been connected to Al-Qaeda or the Islamic State of Iraq and Levant, have also taken place in some major cities in the country, including Jakarta, Surabaya, Solo, Pontianak and Samarinda in 2016, among others.

Beyond their deadly attacks on public spaces like hotels, radical Muslim groups have also targeted houses of worship, destroying churches and forcing others to close in some areas of West Java. In July 2016, a radical group burned Buddhist temples and destroyed Buddhist religious properties in Medan, North Sumatra. Similarly, radical groups have also attacked mosques, schools, Islamic pesantren (boarding schools), offices and so on in Parung-Bogor and Kuningan (West Java), Jakarta, Nusa Tenggara Barat and other areas belonging to the Ahmadiyah, an Islamic sect often not recognised by other Muslims because of its distinctive teachings about prophets more recent than the Prophet Muhammad. Another hardline group attacked and tried to close down several local religious sects. These sects include, among others, the I'tikaf Ngaji Lelaku pesantren led by Yusman Roy, the Cancer and Drug Rehabilitation Center (led by Ardy Hussein), the Salamullah (led by Lia Aminuddin), al-Qiyadah al-Islamiyah (led by Ahmad Mushaddeq) and, most recently, Gafatar (the Fajar Nusantara Movement led by Ahmad Musadeq).

This last case also shows the complicity of the Indonesian Ulama Council (MUI), a government council comprised of leaders of Islamic organisations which issues rulings on social issues as well as licenses for halal food producers. In February 2016, the MUI issued a fatwa (Islamic edict) against Gafatar, declaring it a heretical organisation spreading religious teachings it deemed deviant. The MUI's edict commission (Komisi Fatwa) determined that Gafatar is a successor to the Al Qidayah al-Islamiyah group, which the MUI had previously declared heretical, leading to the prosecution, conviction and imprisonment of its founder on charges of blasphemy. The MUI chairman at the time, KH Makruf Amin, said that Gafatar was deviant because its teachings sought to unify Islamic, Christian and Judaic teachings. Accordingly, Ma'ruf Amin added, Gafatar followers who accepted its teachings should be considered murtad (apostates) and infidels based on Islamic teachings and must repent if they consider themselves Muslims (Jakarta Post, 2016). Once the MUI issued its fatwa, Muslim masses and Islamic paramilitary groups destroyed Gafatar places of worship and looted its property. By March 2016, tens of thousands of Gafatar followers had been expelled from farming settlements in Kalimantan and were 
living as refugees in Java. Fatwas declared by the MUI (at both national and regional levels) have often preceded communal violence; accordingly, some analysts and scholars argue that the MUI has participated in creating and inciting hatred, conflicts and violence. Through fatwa, MUI has also condemned Ahmadiyah as a deviant sect as well as any ideology or social vision associated with pluralism, secularism and liberalism as heterodox schools of thought. Such fatwas are used by radical Muslims as a religious justification for violence against anyone outside their mainstream.

Furthermore, based on the MUI's fatwas, Islamists and Muslim hardliners have also provoked, intimidated and attacked activists from the Liberal Islam Network and the Bulukumba, South Sulawesi office of the Institute for Advocacy and Education of People, an Islam-based non-governmental organisation (NGO) that seeks to counter calls for the application of Sharia law. The most recent data show that hardliners have taken over local mosques, mostly in cities in the northern part of the island of Java. After taking over mosques and building madrasah (Islamic schools) and pesantren, they use them as a means to provoke hatred and enmity toward non-Muslims, especially Christians and Jews, as well as local Muslim groups who are considered less Islamic or sesat.

The Setara Institute for Democracy and Peace reported 371 incidents of religious violence in 2012, the highest level since 2007, and this trend has continued (Fidiyani, 2017). Unfortunately, most remain unresolved. The findings of the most recent survey in 2018 by the Pusat Pengkajian Islam dan Masyarakat (Center for the Study of Islam and Society) at Syarif Hidayatullah State Islamic University, Jakarta also indicated the escalation of the levels of intolerance and radicalism among Indonesian Muslims, including elementary and secondary school teachers. Of the 2,237 teachers surveyed, more than $50 \%$ were found to have intolerant opinions, and more than $46 \%$ had radical opinions (Syambudi, 2019).

Recently, a series of sporadic intolerant and radical acts have occurred in Jakarta and the surrounding regions, triggered by a controversial false video posted on YouTube and circulated widely on the Internet. The video, posted by Buni Yani contained an edited version of a speech by Jakarta's Chinese Christian governor Basuki Tjahaja Purnama (also known as Ahok). In the original speech, the governor warned Muslims not to be fooled by the ulama (religious scholars) who interpret the Qur'anic verse Al-Maida 51 as forbidding Muslims from electing a non-Muslim governor (or any political leader) in Muslim-majority areas. Elected-vice governor in 2012, Ahok, was elevated to the office of governor when his running mate, Joko Widodo, was elected President of the Republic of Indonesia in 2014. Thus, he was on the ballot as a candidate for governor in the 
next election in 2017, which he lost. The video recording widely seen on social media was, in fact, edited by Buni Yani, a provocateur and supporter of another gubernatorial candidate, to suggest that Ahok had directly attacked the Qur'an itself rather than the interpretation given to the Indonesian public. Yani succeeded in angering Muslim groups, instigating demonstrations and forcing the government to put Ahok on trial for blasphemy (Al Qurtuby, 2018).

The widespread cases of violence, intolerant acts and anti-pluralist actions depicted above, when combined with a strong wave of Islamisation as manifested by the formalisation (and imposition) of Islamic law in several regions, poses a serious threat to the future of religious freedom, democracy and civic pluralism in Indonesia. Moreover, outbursts of ethno-religious violence committed by Islamist groups, terrorist organisations, religiously-inspired radicals, intolerant groups and even ex-New Order supporters, have slowed the political reform movements of 1998. The post-New Order's phenomena of violence, intolerance and anti-pluralism also cast doubt on the Muslim community's pluralist experiment and democratic Muslim politics.

The problem of religious radicalism has become more complicated because the Indonesian government, for the most part, has not shown a firm attitude or taken any resolute steps against radical Islamist groups, as can be seen from the hands-off way the state has dealt with these cases. In some cases, government officials at the provincial or regional level have even been involved in or supported intolerant acts committed by religious extremist groups in the name of Islam (Fidiyani, 2017, pp. 109-117). Though the government has arrested terrorists and hunted down their syndicates, it and its security forces have not prevented recent acts of radicalism and other forms of violence committed by Islamist radicals against religious and other minorities (Ahmadis, Shiites, Gafatar and other followers of local sects).

Additionally, some local governments (both provinces and regencies) have themselves issued decrees prohibiting organisations and religious sects or cults that are considered un-Islamic or deviant. This in turn has been used by Islamist paramilitary groups and, in some cases, security personnel (both police and civilians called the Satuan Polisi Pamong Praja) to legalise and legitimise destructive and violent actions. Since the Indonesian government has done little against Islamist extremists, violence and human rights violation are recurring and escalating elsewhere throughout the country, not only in cities but also in semi-urban areas, especially in regions where Islamist organisations have grown.

\section{The Rise of Indonesia's Islamist Militancy}

There are multiple groups, sources and roots of Islamist militancy in contemporary Indonesia (see Hwang [2012, 2018]; Wahid [2014]). While some 
Islamist groups emerged in the Indonesian political stage in the aftermath of President Suharto's resignation in 1998, others existed during or before Suharto's New Order. Due to political repressions during Suharto's era (and even before that period), some Islamist groups hid and worked clandestinely, re-emerging after the Suharto reign collapsed. Some groups are branches of international Islamic organisations (e.g., Hizbut Tahrir, Tablighi Jamaat and Ikhwanul Muslimin), while others were founded in Indonesia (e.g., Islamic Defenders Front, Islamic Community Forum, Laskar Jihad and Jamaah Islamiyah). Yet other Islamist groups are actually only volunteers or supporters of foreign organisations (e.g., Hamas of the Palestine, Islamic State of Iraq and Levant and Abu Sayyaf Group of Mindanao).

It is central to note that although they might share some common features, these groups essentially have different foci, agendas, goals, tactics and strategies. For example, Hizbut Tahrir Indonesia (HTI) is concerned with the founding of an Islamic caliphate. HTI wants to replace the current existing Indonesian foundational ideology (Pancasila), the constitution (Undang-Undang Dasar 1945 [UUD 1945]) and the state form (Negara Kesatuan Republik Indonesia [NKRI]) with an Islamic political system known as caliphate. Other Islamist groups, however, are not interested in the establishment of a caliphate system, focusing on other forms of Islamic political-governmental systems (a non-caliphate Islamic State). Still others emphasise the replacement of secular laws with Sharia Law in the legal system within the framework of the NKRI.

Moreover, some groups (e.g., Tablighi Jamaat) focus on the implementation of the doctrine $a m r m a^{\prime} r u f$ (enjoining right) by introducing forms of ritual practices in accordance with the salaf al-shalih (early generations of Islam) through less-violent methods. Other groups, such as Islamic Defenders Fronts or the Islamic Community Forum, in contrast, emphasise the application of the doctrine nahi munkar (forbidding wrong) towards what they call societal immoral practices (e.g., prostitution, gambling and drugs) that are forbidden by Sharia Law. These groups often, if not always, employ violent means to achieve these goals. Still, whereas some groups support terrorism and suicidal bombings, others reject these acts and consider them evil practices against humanity. Some groups, furthermore, emphasise harsh campaigns against local cultures and traditions as well as aberrant religious practices on behalf of Islamic theological purification.

In brief, there are a variety of Islamist, conservative and paramilitary Muslim groups in post-Suharto Indonesia. Leaders of contemporary neo-Salafi and Islamist movements also vary. Some have Arab origins, while others have Chinese and Indonesian origins. Those of Arab origin include Habib Hussein al- 
Habshi (leader of the Jamaah Ikhwanul Muslimin Indonesia), Rizieq Shihab (founder of the Islamic Defenders Front), Ja'far Umar Thalib (founder of Laskar Jihad), Abu Bakar Ba'asyir (co-founder of Jamaah Islamiyah), the late Habib Selon (Islamic Defenders Font) and Zain Al Kaaf (founder of the National Alliance of Anti-Shiite Movement). Felix Shiauw of HTI represents an Islamist leader of Chinese descent. As for Salafi and Islamist thinkers and leaders of Indonesian origins, they include Bachtiar Nasir, Muhammad Al Khaththat, Abu Jibril, Firanda Andirja, Ismail Yusanto and Tengku Zulkarnain, among others.

Some scholars relate Indonesia's Islamist militancy to neo-Salafism and Islamism (e.g., Barton [2004]; Hasan [2006]; van Bruinessen [2002]). Indeed, although their organisations and religious affiliations vary, the radical Muslim groups that support or commit violence and terrorism identify themselves as having links to either neo-Salafism or Islamism. For example, Abu Bakar Ba'asyir claimed that the most influential books in his life were Fi Dhilal al-Qur'an (In the Shade of the Qur'an) and al-'Adalat al-Ijtima'iyyah fi al-Islam (Social Justice in Islam). These two books were written by Sayyid Qutb (1906-1966), an Egyptian scholar-activist and one of the most influential Islamist thinkers, who has been dubbed the "godfather of modern Islamic radicalism" (Esposito, 2002, p. 56).

In the history of modern Islam and Muslim politics, it is not uncommon to channel religious violence, extremism and global terrorism to particular forms of Islamism or neo-Salafism (Abou El Fadl, 2005; Gold, 2003). Moreover, today's radical Islamists and conservative groups worldwide have indeed justified their violent acts with reference to the ideas of a few seminal Muslim thinkers who rose to international prominence in the 1950s and 1960s, most notably the Egyptian radical activist and ideologue of neo-Salafism Sayyid Qutb (1906-1966) and the Indo-Pakistani theorist of Islamism Abul A'la al-Maududi (1903-1979). Qutb and Maududi have also gained popular support among Indonesian Muslim conservative and radical circles. Other influential foreign Muslim scholars for Indonesian Islamists, Islamic activists and Salafi groups include Muqbil bin Hadi al-Wadi'i (1933-2001), Muhammad Taqi al-Din al-Nabhani (1914-1977), Saleh Al-Fawzan (born 1933), Muhammad Nasirudin al-Albani (1914-1999) and Muhammad ibn al-Uthaymin (1929-2001), among others.

However, it is crucial to understand that not all followers and supporters of neo-Salafism and Islamism commit physical violence, are radical or seed terrorism in the country. A research report by the International Crisis Group (2004) concluded that most Indonesian Salafis find, at least rhetorically, terrorist organisations like the Jama'ah Islamiyah anathema to Islam and humanity. While some involved in terrorism in Indonesia, such as Bali bomber Ali Gufron, claim to be Salafi, the radical fringe that they represent (sometime called salafi 
jihadism) is not representative of the broader movement. Yet, it should be noted that although these organisations verbally reject deadly acts of terrorism such as suicide or non-suicide bombings, they do agree or at least support the other forms of violence and extremism depicted earlier. This is to say that their rejection of terrorist acts does not mean that they are peaceful, tolerant or pluralist. In other words, they reject some acts of terrorism, but they commit or at least support other forms of terrorism and radicalism. Their support for some Muslim hardliners, for instance, can be seen in their thoughts, opinions and actions towards certain types of violence as well as their endorsement of fatwa to incite religious hatred.

In brief, what some Salafis reject is the methods used by terrorist groups to send Islamic messages (e.g., bombings) but not their goals. The late $\mathrm{KH}$ Abdurrahman Wahid (2005), an Indonesian Muslim leader and a leading scholar of Islam, argued that there are at least six goals of Salafi and Islamist groups:

- To restore the perfection of early Islam practiced by the Prophet Muhammad and his companions, who are known in Arabic as al-salaf alshalih or Salafi (the righteous ancestors).

- To establish a utopian society based on Salafi principles.

- To annihilate local variants of Islam in the name of authenticity and purity.

- To transform Islam from a personal faith into an authoritarian political system.

- To establish a pan-Islamic caliphate governed according to the strict tenets of Salafi Islam, often conceived as stretching from Morocco to Indonesia and the Philippines.

- To bring the entire world under the sway of their extremist ideology.

Besides global-international neo-Salafism and Islamism, the post-New Order Islamist militancy is also rooted in the development of Islam during the Suharto era. Some scholars (Hasan, 2006; Hefner, 2000) have pointed out, for instance, that the founding of Dewan Dakwah Islamiyah Indonesia (DDII; the Indonesian Council for Islamic Predication) has been one of the main roots and channels of post-Suharto Islamist radicalism and the neo-Salafi movement. Soon after its founding in 1967, the DDII built close relationships with the Rabitah al'Alam al-Islami (Islamic World League), and by the 1970s, it began to translate and publish Salafi tracts, some of which were notable for their anti-Christian and anti-Jewish diatribes. The DDII also cosponsored the founding of the Institute for Islamic and Arabic Studies based in Jakarta, which offers scholarships to top Muslim students. This institution has become the pivotal conduit for transferring 
conservative Salafi teachings to Indonesia. Many Indonesian Muslim hardliners and religiously-inspired intolerant activists have been trained in this institution. After reformation in 1998, as Indonesians gained more freedom of expression, such radical institutions have appeared throughout the country, from Aceh in the West to Papua in the East (see Wahid [2014]).

Furthermore, local neo-Salafi groups also build madrasah, mosques, pesantren and other Islamic centres affiliated with Salafism. These institutions have been utilised as a base of teachings and even propaganda for Salafi doctrine and Islamist ideology and as a nest of provocation toward other religious communities and Islamic groupings outside their groups, mainstreams and schools of thought. As a result, there has been continuous tension and conflict between Salafis, who support purity, and non-Salafis, who back local traditions and cultural practices in some areas in the country.

Furthermore, the wide spread of neo-Salafism and Islamism is also due to the free access to Salafi and Islamist books that contain "puritanical" teachings and radical practices. These books are mostly intolerant, anti-pluralist and undemocratic as well as being biased against non-Muslims (particularly Jews and Christians), local beliefs, minority Islamic sects and so on. Such teachings definitely contradict the facts of the country's ethno-religious plurality; thereby, it can be understood that such teachings have fuelled tensions and violent conflicts between these conservative-militant groups and local Muslim communities. Last but not least, the public appearance of Salafi ustadhs (teachers) and $d a^{\prime} i$ (preachers) in recent decades - who routinely attack non-Muslim and non-Salafi Muslim religious foundations, practices and beliefs - have also been a major source of tension and conflict (Wahid, 2012, pp. 245-264).

In brief, the emergence of post-Suharto Islamist militancy has been driven by a mixture of international, national and local socio-religious-political factors. Moreover, the dirty collaboration between some factions within the government, parliament or political parties and Muslim groups has shaped the growth of radical Islamist groups and intensified tensions, conflict, intolerance and radicalism in this society. In other words, this political-religious alliance, driven mainly by particular political-economic interests, has contributed to the deepening or radicalisation processes of Islamist and Salafi groups. Other Islamist groups have been backed by retired military/police elites or deposed politicians and bureaucrats. These opposing groups of political elites have used Islamists to attack their political rivals, as in the recent and ongoing cases of opposition between President Joko Widodo (and also former Jakarta governor Basuki Tjahaja Purnama) and their political rivals (e.g. Prabowo Subianto or 
Anies Baswedan), who built an alliance with radical and intolerant Islamist factions (Al Qurtuby, 2018, 2019).

\section{Conflict Resolution and Strategic Peacebuilding as Approaches to Militant Islamist Intolerance}

Now, the critical question becomes: is there any way to resolve the intolerance, conflict and violence in this archipelagic country? Is there any better approach, strategy or tactic to build peace, harmony and civil coexistence among Indonesia's plural religious groups and complex societies?

I suggest that to neutralise the virulent ideologies that have led to Islamist militancy threatening civic pluralism (which is the foundation of Indonesia as an independent nation-state), those interested in building peace and tolerance in this society must do the following. They must identify Islamist ideologues, understand their goals and strategies, evaluate their strengths and weaknesses, and effectively counter their every move. More specifically, activists and practitioners of conflict resolution and peacebuilding - at both state and society levels - need to employ effective strategies to counter each of the strengths of radical extremism.

These strategies can be accomplished by uniting the vast majority of the Indonesian people, both Muslim and non-Muslim, who want peace from violence in a coordinated global campaign against intolerance and radicalism. Additionally, the government (state institutions and apparatuses) and society (NGOs and civil society associations) as well as individuals who are concerned with inter- and intragroup peace, harmony and stability need to employ multiple approaches, strategies and techniques of peacebuilding and conflict transformation, including involving radical factions in the conciliation and reconciliation processes.

This is to say that countering the multifaceted and complex threat of radicalism and terrorism requires a broadly cooperative effort involving religious, legal, economic, political, cultural and military cooperation from virtually every organisation and group in the country (Cortright \& Lopez, 2007, pp. 2-3). Indonesia will never succeed in countering terror and militancy if the government's tools work in isolation from, or in conflict with, one another. Terrorists, radicals and Islamists can die, but ideology never will.

There are multiple strategic approaches to conflict transformation and peacebuilding that can be used by intra-/interfaith activists, conflict resolution practitioners and peacebuilders, either in government or society in general, as a tool to counter militancy, radicalism and terrorism. These methods include legal- 
justice approaches, cultural and persuasive approaches, education/learning and dialogue.

A legal-justice approach, most often proposed by human rights activists, aims to protect human rights through laws and the constitution. This approach, according to some peace studies specialists (Lederach, 1996; Schirch, 2004), is a coercive strategy of peacebuilding that includes protests, demonstrations, smart sanctions, threats by the international community and so on. These methods aim at pressuring decision and policymakers to prosecute human rights violators and perpetrators of violence and intolerance as well as to provide for people's basic needs, which is part of the essential efforts of peacebuilding and conflict transformation. Many unmet human needs have become active elements in causing ethnoreligious tensions and violence. These needs include basic issues of material resources, psychological trauma and empowerment as well as needs for integration, respect and uniqueness (Gopin, 2000, pp. 5-6). To have maximum impact, peace activists and conflict resolution practitioners should coordinate with key people (including influential and charismatic figures, stakeholders, power holders, etc.), the mass media, business communities, scholars, religious leaders, youth, women's groups and students, among others.

Furthermore, there are at least three major strategies to reduce violence as a short-term objective and to establish peace as a long-term goal. First, it is necessary to create and raise public awareness of the danger of violence as the common enemy rather than focusing on certain groups. Raising awareness and increasing understanding that groups in conflict are interdependent is an important but difficult step in social movements (Lederach, 1996). Many assume and think that violence committed by radical Islamists is only addressed at specific minority groups (e.g., Christians, Shiites, Ahmadiyah or moderate/liberal Muslims) but not other societies in general. On the contrary, violence has become a global threat for all areas of society, including businesses, small traders, laborers and ordinary people/Muslims, among others. Thereby, raising collective awareness toward violence as a common enemy is an essential strategy. Quaker conciliator Adam Curle (1971) suggested the application of three key peacebuilding efforts to raise people's awareness, namely education, advocacy and mediation. For Curle, education or conscientisation are most needed when the conflict is hidden and people are unaware of imbalance and injustices.

The second strategy is organising and mobilising people that have similar concerns and objectives to take nonviolent action. The purpose of this strategy is to create people power and to balance the power. Within sociopolitical movements, people power has become a key method for change and reformation throughout the world, including in South Africa, India, the US and 
Latin America (Bondurant, 1988; Lynd, 1966). It is therefore important to organise and mobilise the moderate majority of people, Muslim and non-Muslim alike, because although they denounce acts of radicalism and terrorism as contemptible, they often take a silent attitude against such violence. In other words, it is necessary to transform the silent majority to become the noisy majority who voice the vitality of intergroup tolerance and civic peace.

Third, it is also necessary to persuade and lobby both potential and current influential figures to intervene publicly. These figures are essential for two fundamental reasons. First, they hold the power to influence and pressure the government and policymakers to take firm attitudes and resolute steps by bringing actors of violence, intolerance and human rights violations to court and to provide for people's basic needs (e.g., safety and freedom). Second, they can sway public opinion by stirring people who are unaware, passive or apathetic. Influential moderate figures include stakeholders, charismatic leaders who have traditional or religious authority (e.g., ulama, clerics and adat chiefs) and power holders (i.e., influential political figures), among others.

Peacebuilders and conflict resolution practitioners need to use or maximise the role of these influential figures because these figures are able to directly communicate with high-ranking bureaucrats, military elites and policymakers. Likewise, in stratified and ranked societies like that of Indonesia, these figures have a critical role in influencing decision and policymakers and in awakening people power. Habib Lutfi bin Yahya, Kiai Maimun Zubair, Kiai Mustafa Bisri, Habib Muhammad Quraish Shihab, Kiai Makruf Amin, Kiai Said Aqiel Siradj, Buya Ahmad Syafi'i Ma'arif and Habib Syech bin Abdul Qadir Assegaf are among the influential charismatic religious clerics and Muslim leaders. They have close contact with high-ranking government officials, policymakers and military/police commanders, who peace and conflict resolution practitioners need to work with. They also play a role in promoting inter- and intragroup peace and tolerance in the country.

Moreover, the legitimate basis of the legal-justice approach is that Islamists and extremists have blatantly violated human rights and clearly transgressed the Indonesian Constitution (UUD 1945) and the Pancasila state ideology and philosophy. Article 28 of the constitution states:

(1) Every citizen has the right to hold religious beliefs and pray according to these beliefs, choose his/her education and form of teaching, choose his/her job, choose his/her citizenship, and live in this country, leave and return to the country; and (2) Every citizen has the right to hold personal beliefs and express his/her thoughts and attitudes according to what he/she believes is right. 
Based on this constitution, the government must act firmly against all those who violate and transgress basic principles of human rights, including rights to freely express religion and faith. The acts committed by militant Islamists are not simply crimes but also a violation of the Indonesian constitution (UUD 1945) and human rights laws (e.g., the Universal Declaration of Human Rights 1948 and the Universal Islamic Declaration of Human Rights 1981). If the government tolerates such abuse of religious freedom and tolerance or fails to punish the perpetrators, tensions and violence will continue to occur in the future. Accordingly, the legal-justice approach is significant and essential to stop such violence and establish immediate peace. The government's actions against violators of human rights, however, should be nonviolent in accordance with the law and should not deploy military force.

Another conflict transformation and peacebuilding method that needs to be highlighted here is the persuasive or cultural approach. The cultural approach is a peacebuilding approach that strengthens or maximises the application of religious-cultural values, local traditions, rituals, local wisdom, myths, religious symbols, etc. As the largest archipelagic country in the world, consisting of more than 17,000 islands and hundreds of tribal societies and ethnic groups, Indonesia has plentiful local values, cultures and traditions that can be applied to conflict intervention and peacebuilding.

Indeed, Indonesia has a variety of traditional indigenous approaches to decision making and conflict resolution. For many years, ethnic groups and societies in the country have used consensually-based deliberative procedures for handling a variety of issues that emerge in the process of living together in a community. These consensually-based approaches have their roots in selfgoverning systems of deliberation and village justice found on most islands throughout the country. One of the consensually-based approaches is musyawarah derived from Arabic shura, which is a type of decision-making process and peaceful indigenous dispute resolution practice. More specifically, this term refers to a group's deliberative process, the goal of which is to achieve mufakat (consensus), which is generally seen by Indonesians as a solution that all concerned parties find acceptable. Ideally, mufakat is supported by all concerned parties with unanimous acclaim. In short, a win-win solution is the main objective of musyawarah. Because of the tight links between musyawarah and mufakat, these terms have been united to become musyawarah untuk mufakat (i.e., group deliberation for [achieving] consensus). Other examples of these deliberative procedures include the runggun in Batak, North Sumatra, baku bae (reconciliation) in Central Maluku, meetings between councils of elders from 
Javanese villages, discussion groups of the Bukat and Kereho in Kalimantan or clan-based decision-making procedures in Papua, among others.

In Maluku, where communal violence involving Christian fighters and Muslim jihadists broke out for several years from 1999 to 2004, local societies utilised peacebuilding mechanisms and conflict resolution practices such as baku bae, an indigenous practice to settle disputes. One study (van Tongeren, Brenk, Hellema, \& Verhoeven, 2005, pp. 667-672) pointed out that Gerakan Baku Bae (the Baku Bae Movement) helped reduce violence in Maluku and paved the way for the signing of a 2002 peace accord between two warring parties, brokered by the central government. The concept of baku bae can be seen as an indigenous way of rebuilding social capital and restoring trust through dialogue and community focus.

Besides baku bae, societies in Maluku also acknowledge pela gandong, an Indigenous cultural and social cohesion based on the traditional kinship system. Prior to the advent of Islam and Christianity in the region, local societies based their relationships on this traditional principle. The arrival of Islam and Christianity (first with Catholicism followed by Protestantism), and was radicalised by the European colonials, drove local societies to form religiouslybased divisions, namely sarane (Christian community) and salam (Muslim community). Historically, these two religious groups have been susceptible to tension and conflict and easily driven to violence. The pela gandong has thus been useful for local societies as a cultural and traditional way of building peace and resolving conflicts between these religious groups (Tulalessy, 2005).

Furthermore, religious rituals and local traditions can also be used as culturally powerful resources for peacebuilding and conflict transformation. In Indonesia, local Islamic rituals such as istighatsah (public ritual sermons) have been widely used by many local imam (prayer leaders); modin (rural/local religious authorities); kiai, ajengan or tuang guru (local clrerics); ustad; habib (a person having a bloodline traced back to the Prophet Muhammad) and so on. The term istighatsah refers to public gatherings that involve a huge number of Muslims at a specific location (i.e., soccer fields, stadiums or big mosques). During this gathering, Islamic clerics take turns leading the sermons by reciting verses of Al-Qur'an. Istighfar (asking amnesty for sins from God), preaching and religious sermons also occur. From Indonesian Muslims' points of view, this Islamic cultural instrument is very important and an essential method of peacebuilding and resisting violence. In fact, both religious and political leaders, including high-ranking bureaucrats and top government officials, have often used the istighatsah to calm tensions and reduce conflict. On December 2, 2016, when Indonesia had almost turned into sectarian violence, hundreds of 
thousands of Muslims gathered around Monas, Jakarta's iconic monument, for istighatsah, Friday prayer and religious sermons. Led by KH Makruf Amin, who at the time was MUI Chairman and Supreme Leader of Nahdlatul Ulama (now the running mate of the incumbent President Joko Widodo for the 2019 presidential election), this colossal religious event was also attended by President Joko Widodo, Vice President Jusuf Kalla, ministers, high-ranked bureaucrats, police and military generals. Many Indonesians considered this religious event successful in reducing tensions, defusing conflict and transforming the masses from anger to peace and from discord to concord.

Moreover, another important cultural approach is education and learning. Human rights education and learning are key to respecting others' thoughts and religious beliefs and are the foundation of a culture of tolerance and pluralism. Education has a greater democratic benefit when it conveys a spirit of intellectual bridging rather than exclusive bonding. Likewise, education has powerful social capital for creating cultural bases for strategic peacebuilding (Halpern, 2005). A lack of understanding of other religions and communities often becomes the root and partial cause of conflicts and religious-based violence. However, respect, tolerance, pluralism and human dignity cannot be reached or imposed by military forces, violence or confrontation.

I am certain that if educational curricula in Indonesia were based on cross-cultural understanding (CCU), heterogeneous/pluralistic concepts, interfaith principles and mutual understanding among religions/beliefs, then plurality would be achieved. The country's educational institutions (including universities and secondary and elementary schools) are, for the most part, too exclusive in the sense that they do not comprehensively teach religious understanding and inclusivity by religious scholars. The effect of this type of education produces narrow-minded disciples (and teachers) who embrace exclusive, conservative, intolerant or even radical views and opinions towards other religious groups, as proved by the 2018 survey findings by the Center for the Study of Islam and Society or the research outcomes conducted by the Wahid Institute. In contrast, CCU-based education can open students' minds to the importance and meaning of heterogeneity so that they will respect and appreciate other religions, Muslim groups, religious sects and local beliefs as part of society. Inter-religious education encourages respect and tolerance for people of other faiths and prepares students to cast aside barriers of prejudice and intolerance.

In peacebuilding, diversity and tolerance of differences are focal principles. Even Islam, as asserted by leading Muslim peace scholar Mohammed Abu-Nimer (2003, p. 82), underlines principles of pluralism, tolerance of 
differences and unity in diversity as God's wish because He created a diverse rather than a uniform human race (see, for example, Q. 11:118, Q. 5:48). Moreover, the Qur'an grants diversity and tolerance of differences based on gender (Q. 53:45), skin colour, language (Q. 30:23), belief and rank (Q. 64:2). If such values are taught to students from the beginnings of their educations and they are introduced to abundant Islamic resources that evoke pluralism, democracy, tolerance and the like, they will become powerful resources for peacebuilding work in the future.

There are two additional reasons for stressing investments in education. First and foremost, education is what the great majority of modern Muslims yearn for. Second, education is the most paradigmatic of modern cultural institutions. As noted by Robert Hefner (2005), today, "no society can compete even in the lower rungs of the global order without a well-run educational system" (p. 27). Hefner (2005) added, "in its diverse specializations, its encouragement of innovation, its gender equality, and its culture of civility-inplurality [emphasis added], higher education is a shimmering example of all that is best about modern freedom and civic decency" (p. 27).

Indonesia has some 10,000 Islamic pesantren and 37,000 Islamic madrasah (Hefner \& Zaman, 2007, p. 173). Most of these schools are linked to Nahdlatul Ulama and Muhammadiyah, the largest and second largest Muslim organisations. Both Nahdlatul Ulama and Muhammadiyah are essential agents of peacebuilding and conflict transformation due to their religious commitments to pluralism, moderation, democracy, tolerance and other basic human values. If designed properly, these Islamic educational institutions can be used as potential cultural resources for planting Islamic teaching of these values (Sachedina, 2001). In the future, such institutions will be able to create cadres of pluralist and moderate Muslims to block the movement and reduce the influence of radical Islamists. As described earlier, radical Muslim groups in the country have also used educational institutions to disseminate puritanical teachings, breed doctrines of Salafism and Islamism, brainwash local Indonesian Muslims and provoke religious hatred against outside religious groups. From this point of view, anyone concerned with peace, freedom and democracy needs to revive the importance of these Islamic educational institutions and schools.

Besides formal educational institutions (from madrasah to higher institutions), education and learning processes that plant and disseminate values of pluralism, tolerance, democratic civility and mutual understanding can be offered through traditional Islamic institutions or places of worship. Indonesia has numerous places of worship and traditional Islamic institutions (see Hefner and Zaman [2007, pp. 172-198]), which are considered by local Muslims as 
sacred and meaningful places and which can be used for building religious dialogue and peace. These sites and institutions include masjid (mosques), mushalla or langgar (smaller prayer places), pesanggrahan (meeting rooms of local Islamic kingdoms), pesantren, pondok (Islamic boarding schools in Kalimantan, South Sulawesi), surau (Islamic boarding schools in West Sumatra) and dayah (traditional schools in Aceh). Those interested in establishing societal harmony and peace can also utilise nongovernmental public cultural spheres and informal meeting forums to solve conflict and social problems.

Last but not the least, another important cultural approach is dialogue, namely an ongoing communication process to understand the thoughts, minds, worldviews, teachings, systems of belief and philosophies of life of other communities (Mennonite Conciliation Service, 2005, pp. 206-208). Dialogue ideally involves both moderate and extremist factions, which can be reached through negotiation, mediation or facilitation by involving go-betweens, who are people with similar concerns and objectives to build peace and resolve conflict. The go-betweens could be human rights/NGO activists, interfaith communities, experts, ex-militant groups, governments, stakeholders and educators, among others. Coordination among networks can strengthen and sharpen dialogue processes to seek common ground and to maximise outcomes. An example of such is the West African Networks of Peacebuilding, which involves a wide variety of actors who are concerned about issues of inter-religious conflict (Schirch, 2006, p. 68).

Dialogue can also be achieved informally. As a cultural bridge to open up deadlocks, dialogue is an effective communication tool for creating mutual understanding and trust among parties. Many times, tensions, disturbances and conflicts, including human rights' violations, occur because of a lack of communication. Dialogue also requires commitment and willingness to seek other truths. Additionally, in an interfaith dialogue process, participants need to address not only the similarities between each religion but their differences as well. Moreover, an ongoing, healthy and constructive dialogue can function as a way to move from ethnocentrism to ethno-relativism. Whereas ethnocentrism is an assumption that one's own culture is central to all reality, ethno-relativism is the assumption that cultures can only be understood relative to one another and that particular behaviours can only be understood within a cultural context (Bennett, 1993, pp. 1-51). Those who actively engage in interfaith dialogue and cross-cultural encounters realise that moving from an ethnocentric perspective to an ethno-relative outlook is a lengthy journey. Accordingly, those who are involved in the dialogue process need a strong commitment, significant 
motivation and sincere intention to fully and totally engage with outsiders for the sake of peacebuilding and the creation of global justice.

Hans Kung (born 1928), a theologian and president of the Foundation for a Global Ethic (an international NGO promoting religious dialogue and peace), also recognised the vitality of religious dialogue. He famously stated, "No peace among the nations without peace among the religions. No peace among religions without dialogue between the religions. No dialogue between the religions without investigation of the foundation of the religions" (Kung, 2007, p. xxiii). Kung has made clear that the investigation of religious foundations through CCU, education, interfaith encounters and inter-religious dialogue is the basis of sustainable strategic peacebuilding worldwide, including in Indonesia. Thus, dialogue, if conducted wisely and properly, can become a miraculous way of transforming conflict and building enduring peace.

\section{Conclusion}

The descriptions and analyses above suggest that Islam (in fact any religion) can be abused or hijacked as a source of violence and simultaneously used as a resource for peace depending on the actors' interests and objectives. While radicals tend to misuse religious sources to incite intolerance and radicalism, moderates have a tendency to utilise religious sources to build tolerance and peace in society. Jewish scholar Marc Gopin (2000) reminded us that "[s]ome believers creatively integrate their spiritual tradition and peacemaking, [but] many others engage in some of the most destabilizing violence confronting the global community today" (p. 13). Although religion has so often inspired, legitimated, radicalised and exacerbated intolerant acts, anti-pluralist actions and violent conflicts, it can also contribute to their peaceful resolution.

Religion, for some fanatics and radicals, can be an essential source of violence and terrorism since it gives moral justifications and religious legitimacy for discriminating, eliminating or even killing others and provides images of cosmic war that allow radical activists to believe that they are waging spiritual battles. However, this does not mean that religion (including Islam) by itself causes violence, nor does it mean that religious violence cannot, in some cases, be justified by other means. But it does mean that religion often provides the mores and symbols that make violence, radicalism, and other catastrophic acts of terrorism possible (Juergensmeyer, 2003).

This is to say that religion is ambivalent; on one hand, it can be used as a powerful and potential resource for conflict transformation, reconciliation and peacebuilding. On the other hand, it can also be used or abused as a religious basis and moral foundation for destabilising the world order through global 
radicalism, international terrorism and transnational violent conflicts (Appleby, 2000).

Moreover, in order to solve violence and to prevent radicalism and intolerance from occurring in the future, those concerned with peace must apply multiple conflict transformation and peacebuilding approaches that combine legal, political, cultural and religious forces. All elements within state and society need to work together to establish peace and tolerance. Furthermore, those concerned with peacebuilding and social stability in the country need to look for ways to extend beyond the liberal peace frameworks that solely emphasise the role of formal peace accords, cease-fires, elections and short-run peace operations carried out by international institutions, Western states and political elites in attempts at building lasting peace in conflict-ravaged societies. Although liberal peace is necessary, it is not enough to establish a just and sustainable peace (Philpott \& Powers, 2010). Those concerned with peacebuilding and conflict transformation in societies plagued by violent conflicts and religious radicalism, like Indonesia, need to combine both secular and religious voices and provide avenues for policing and establishing enduring peace and conflict resolution.

There is certainly no simple solution for preventing radicalism and pacifying radicals. However, if many elements in the society - secular and religious or moderate and conservative alike - work together, there is hope for future enduring peace and tolerance. More importantly, besides utilising cultural means of peacebuilding, the Indonesian government should take serious and firm action against those who commit intolerant, anti-pluralist and violent acts in their country. The government must take action against intolerant radicals simply because they have blatantly transgressed the constitution and other governmental laws, devalued humanity, disrespected plurality and disregarded the Indonesian national motto: Bhineka Tunggal Ika (unity in diversity). If the government fails to decisively act against intolerant radicals in accordance with the law, intolerance, anti-pluralist movements and radicalism will recur in the future. Only by combining these multiple approaches can peaceful coexistence, religious tolerance and civic pluralism be productively achieved in the archipelagic country of Indonesia in the years to come.

\section{References}

Abou El Fadl, K. (2005). The great theft: Wrestling Islam from the extremists. New York, NY: Harper.

Abu-Nimer, M. (2003). Nonviolence and peacebuilding in Islam: Theory and practice. Gainesville, FL: University Press of Florida. 
Al Qurtuby, S. (2016). Religious violence and conciliation in Indonesia: Christians and Muslims in the Moluccas. London, UK: Routledge.

Al Qurtuby, S. (2018). Indonesia's Islamist mobilization, Kyoto Review of Southeast Asia, 23. Retrieved from https://kyotoreview.org/issue-23/indonesiasislamist-mobilization/

Al Qurtuby, S. (2019, April 24). The 2019 election in Indonesia: The battle between 'Jokowi lovers' and 'Jokowi haters'. Maydan. Retrieved from https://www.themaydan.com/2019/04/the-2019-election-in-indonesia-thebattle-between-jokowi-lovers-and-jokowi-haters/

Appleby, S. (2000). The ambivalence of the sacred: Religion, violence, and reconciliation. Lanham, MD: Roman and Littlefield Publishers, Inc.

Barton, G. (2004). Indonesia's struggle: Jamaah Islamiyah and the soul of Islam. Sidney, Australia: University of New South Wales Press.

Bennett, M. J. (1993). Towards ethnorelativism: A developmental model of intercultural sensitivity. In R. M. Paige (Ed.), Education for the intercultural experience (pp. 1-51). Yarmouth, ME: Intercultural Press.

Bertrand, J. (2004). Nationalism and ethnic conflict in Indonesia. Cambridge, UK: Cambridge University Press.

Bondurant, J. (1988). Conquest of violence: The Gandhian philosophy of conflict. Princeton, NJ: Princeton University Press.

Brauchler, B. (2011). Reconciling Indonesia: Grassroots agency for peace. London, UK: Routledge.

Brauchler, B. (2016). The cultural dimension of peace: Decentralization and reconciliation in Indonesia. New York, NY: Palgrave Macmillan.

Cortright, D., \& Lopez, G. (2007). Uniting against terror: Cooperative non-military responses to the global terrorist threat. Cambridge, MA: The MIT Press.

Curle, A. (1971). Making peace. London, UK: Hawthorne Press.

Duncan, C. R. (2013). Violence and vengeance: Religious conflict and its aftermath in Eastern Indonesia. Ithaca, NY: Cornell University Press.

Esposito, J. L. (2002). Unholy war: Terror in the name of Islam. New York, NY: Oxford University Press.

Fidiyani, R. (2017). State legal protection on freedom of religion: A myth. Advances in Social Science, Education and Humanities Research, 162, 109-117.

Gold, D. (2003). Hatred's kingdom: How Saudi Arabia supports the new global terrorism. Washington, DC: Regnery Publishing, Inc.

Gopin, M. (2000). Between Eden and Armageddon: The future of world religions, violence, and peacemaking. New York, NY: Oxford University Press.

Halpern, D. (2005). Social capital. Boston, MA: Polity Press. 
Hasan, N. (2006). Laskar Jihad: Islam, militancy, and the quest of identity in post-New Order Indonesia. Ithaca, NY: Cornell Southeast Asia Program Publications.

Hefner, R. W. (2000). Civil Islam: Muslims and democratization in Indonesia. Princeton, NJ: Princeton University Press.

Hefner, R. W. (2005). Muslim democrats and Islamist violence in post-Suharto Indonesia. In R. W. Hefner (Ed.), Remaking Muslim politics: Pluralism, contestation, and democratization (pp. 273-301). Princeton, NJ: Princeton University Press.

Hefner, R. W., \& Zaman, M. Q. (Eds.). (2007). Schooling Islam: The culture and politics of modern Muslim education. Princeton, NJ: Princeton University Press.

Hwang, J. C. (2012). Peaceful Islamist mobilization in the Muslim world: What went right. New York, NY: Palgrave Macmillan.

Hwang, J. C. (2018). Why terrorists quit: The disengagement of Indonesian jihadists. Ithaca, NY: Cornell University Press.

International Crisis Group. (2004). Indonesia backgrounder: Why Salafism and terrorism mostly don't mix (Report No. 83). Retrieved from https://www.crisisgroup.org/asia/south-east-asia/indonesia/indonesiabackgrounder-why-salafism-and-terrorism-mostly-dont-mix

Jakarta Post. (2016, February 3). Gafatar is heretical: MUI. Retrieved from http://www.thejakartapost.com/news/2016/02/03/gafatar-hereticalmui.html

Juergensmeyer, M. (2003). Terror in the mind of God: The global rise of religious violence. Berkeley, CA: University of California Press.

Kholiludin, T. (2016). Laporan tahunan kebebasan beragama dan berkeyakinan di Jawa Tengah Tahun 2015. Semarang: eLSA Press.

Kung, H. (2007). Islam: Past, Present and Future. Oxford, UK: Oneworld Publications.

Lederach, J. P. (1996). Preparing for peace: Conflict transformation across cultures. Syracuse, NY: Syracuse University Press.

Lynd, S. (1966). Nonviolence in America: A documentary history. Indianapolis, IN: The Bobbs-Merrill Company, Inc.

Mennonite Conciliation Service. (2005). Mediation and facilitation training manual. Akron, OH: Mennonite Central Committee.

Philpott, D. (2012). Just and unjust peace: An ethic of political reconciliation. Oxford, UK: Oxford University Press.

Philpott, D., \& Powers, G. (2010). Strategies of peace: Transforming conflict in a violent world. London, UK: Oxford University Press. 
Sachedina, A. (2001). The Islamic roots of democratic pluralism. Oxford, UK: Oxford University Press.

Schirch, L. (2004). The little book of strategic peacebuilding. Intercourse, PA: Good Books.

Schirch, L. (2006). A peacebuilding framework to link human rights and conflict transformation approaches. In J. Mertus \& J. Helsing (Eds.), Human rights and conflict: Exploring the links between rights, law, and peacebuilding (pp. 6396). Washington, DC: U.S. Institute of Peace.

Sidel, J. (2006). Riots, pogroms, jihad: Religious violence in Indonesia. Ithaca, NY: Cornell University Press.

Syambudi, I. (2019, February 7). Survei PPIM 2018: 56,9\% guru di Indonesia beropini intoleran. Tirto.id. Retrieved from https://tirto.id/survei-ppim2018-569-persen-guru-indonesia-beropini-intoleran-dgbp

Tibi, B. (2012). Islamism and Islam. New Haven, CT: Yale University Press.

Tulalessy, I. (2005, May 19). Pela Gadong sebagai katup pengaman di Maluku [Pela Gadong as a safety valve in Maluku]. Sinar Harapan, p. 4

van Bruinessen, M. (2002). Genealogies of Islamic radicalism in post-Suharto Indonesia, Southeast Asia Research, 10(2), 117-154.

van Klinken, G. (2007). Communal violence and democratization in Indonesia. London, UK: Routledge.

van Tongeren, P., Brenk, M., Hellema, M., \& Verhoeven, J. (Eds.). (2005). People building peace II: Successful story of civil society. Boulder, CL: Lynne Rienner Publishers, Inc.

Wahid, A. (2005, December 12). Right Islam vs. wrong Islam. Wall Street Journal, pp. 5-6.

Wahid, D. (2012). Challenging religious authority: The emergence of Salafi Ustadhs in Indonesia. Journal of Indonesian Islam, 6, 245-264.

Wahid, D. (2014). Nurturing the Salafi Manhaj: A study of Salafi Pesantren in contemporary Indonesia. Doctoral thesis, Universiteit Utrecht, Utrecht, the Netherlands.

Wilson, C. (2008). Ethno-religious violence in Indonesia: From soil to God. London, UK: Routledge. 